\title{
Economic Vulnerability and Financial Fragility
}

\author{
William R. Emmons and Bryan J. Noeth
}

Unfortunately, many families with the greatest exposure to the economic dislocations of the recent recession also had very risky balance sheets beforehand that were characterized by low levels of liquid assets, high portfolio concentrations in housing, and relatively high balance-sheet leverage. The authors argue that economic vulnerability and risky balance sheets are correlated because they derive from common factors. These factors include a low stock of human capital, inexperience (relative youth), and, in some cases, the legacy of discrimination in housing, education, and employment. Innate cognitive ability interacts with formal education and on-the-job experience to build human capital, while the legacy of discrimination may attenuate the translation of cognitive ability and education into human capital. Acquiring financial knowledge of risk management also requires time and experience and is more valuable to those with high levels of human capital and savings available to invest. Given the combination of these factors, individuals and families who are young, less cognitively able, and/or members of historically disadvantaged minorities are more likely to be economically vulnerable and to hold risky balance sheets because they lack financial knowledge and experience. Moreover, balance sheets of economically vulnerable families before the recent recession were especially risky after a decade of financial liberalization and innovation that increased the access of such families to homeownership and historically high leverage. Economically vulnerable families should avoid "doubling down" with risky balance sheets to enhance their future household financial stability. (JEL D14, D11, D12)

Federal Reserve Bank of St. Louis Review, September/October 2013, 95(5), pp. 361-88.

William R. Emmons is an assistant vice president and Bryan J. Noeth is a policy analyst at the Federal Reserve Bank of St. Louis. This paper was prepared for presentation at the symposium, "Restoring Household Financial Stability after the Great Recession: Why Household Balance Sheets Matter," sponsored by the Federal Reserve Bank of St. Louis and Washington University in St. Louis, February 5-7, 2013.

○ 2013, The Federal Reserve Bank of St. Louis. The views expressed in this article are those of the author(s) and do not necessarily reflect the views of the Federal Reserve System, the Board of Governors, or the regional Federal Reserve Banks. Articles may be reprinted, reproduced, published, distributed, displayed, and transmitted in their entirety if copyright notice, author name(s), and full citation are included. Abstracts, synopses, and other derivative works may be made only with prior written permission of the Federal Reserve Bank of St. Louis. 


\section{Emmons and Noeth}

\section{Figure 1}

\section{Unemployment Rates}

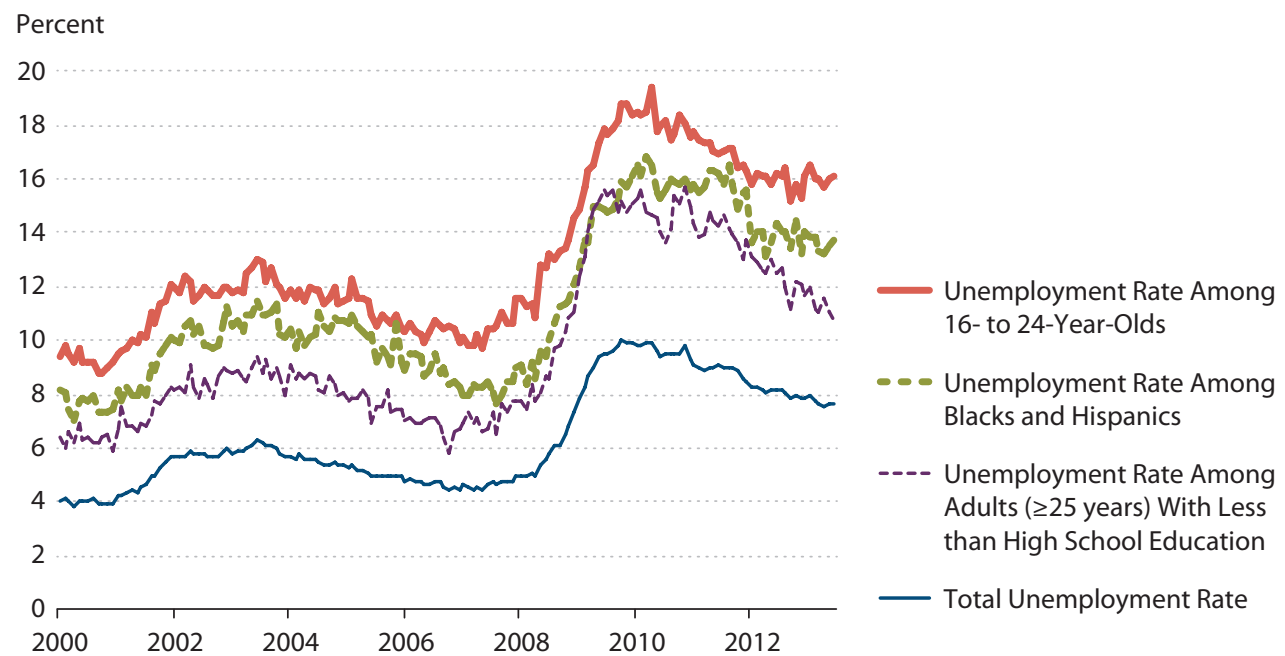

SOURCE: Bureau of Labor Statistics/Haver.

These economically vulnerable groups also suffered greatly in financial terms. For example, the 2010 average wealth of households younger than 40 years of age, with a two- or four-year college degree, and within an historically disadvantaged minority group (black or Hispanic) was $\$ 33,154$. This is 66 percent lower than their 2007 average. $\stackrel{2}{2}$ The 2010 average wealth of households younger than 40 years of age, but with less than a high school education and not a part of an historically disadvantaged minority group (primarily white or Asian) was $\$ 22,008$. This is 74 percent lower than their 2007 average. Most other subgroups with one or more of these demographic characteristics also suffered above-average wealth losses. $\underline{3}$

Why did the demographic groups hardest hit by the recession also suffer enormous financial losses? The answer is not as obvious as it might at first appear. Economic and financial crosscurrents-including rising unemployment, falling asset prices, and different wealth accumulation patterns-affected various households in different ways. Households at greater ex ante risk of job loss and other economic setbacks-the economically vulnerable-indeed suffered more unemployment spells and other income interruption than other groups. $\stackrel{4}{ }$ On the other hand, these same households presumably knew they were at greater risk of job loss than other families. They might have had higher precautionary savings and chosen relatively safe balance sheets to compensate for their elevated economic risk. $\underline{5}$ Such circumstances would imply relatively high saving propensities; large stocks of safe and liquid assets relative to income to respond to emergencies; a broadly diversified asset portfolio to hedge against the collapse of any asset class; and low balance-sheet leverage (i.e., debt-to-assets ratio) to minimize both the amplification of asset price declines on net worth and the risk of defaulting on a debt. 
Moreover, economically vulnerable families generally have relatively low permanent incomes and low wealth-to-income ratios. 6 Because such families had comparatively little wealth before the crisis, their total lifetime resources presumably were less affected by asset price declines. In contrast, older, more highly educated, and nonminority families typically had much greater wealth and larger shares of their lifetime resources at risk in financial and housing markets. After the trauma of 2007-09, large declines in asset prices presented an unusually favorable opportunity for families with relatively low pre-crisis exposure to these markets to accumulate assets at bargain prices. Extremely low interest rates in the aftermath of the crisis likewise could be especially valuable to struggling families who wanted to refinance existing debt or assume new debt to buy a house, pay for education or training, or start a new business.

It is therefore not obvious why economically vulnerable groups of families experienced such large percentage wealth losses. As it turns out, economically vulnerable families also typically exhibited risky financial behavior and had risky balance sheets before the crisis. In particular, young, less-educated, and minority families had saving propensities significantly lower than their older, better-educated, and nonminority counterparts. - Their homeownership rates increased by above-average amounts in the decade preceding the crisis and their share of housing in total assets was higher than for economically less vulnerable families (see Emmons and Noeth, 2013). Balance-sheet leverage and debt-to-income ratios were higher and increased more in the years leading up to the Great Recession (see Emmons and Noeth, 2013).

The huge wealth declines of these families during the crisis, as well as their apparently limited ability to take advantage of low asset prices and interest rates in 2009 and 2010, followed directly from their pre-crisis balance sheets. Rather than providing a bulwark against the economic storm, the balance sheets of many economically vulnerable families collapsed just as their earnings from work declined or vanished.

Our article is organized as follows. In the next section, we provide a framework based on the work of Lusardi, Michaud, and Mitchell (2013) to better understand why so many economically vulnerable families entered the recession with very risky balance sheets. This approach does not rely on differing rates of time preference or risk aversion to generate differences in behavior toward financial risk. Instead, the key insights are that financial knowledge (i) is costly, (ii) takes time to acquire, and (iii) is of greater value to families with greater anticipated earning power during the middle years of their life spans that they would like to shift forward into retirement. We then document the heterogeneity of balance sheets in 2007 across the demographic dimensions of age, educational attainment, and race or ethnicity, emphasizing the riskiness of the average balance sheet among economically vulnerable groups. Next, we show the financial results of holding risky balance sheets during the Great Recession. A separate section provides regression evidence that helps us determine the relative importance of demographic factors in driving risky portfolio choice. We find that relative youth, perhaps more than any other factor, explains risky financial behavior before the crisis and the ensuing large wealth losses. The final section concludes with a discussion of commonly proposed intervention strategies that attempt to break the link between economic vulnerability and financial fragility. 


\section{Figure 2}

\section{Earnings Determination and Balance-Sheet Choice}

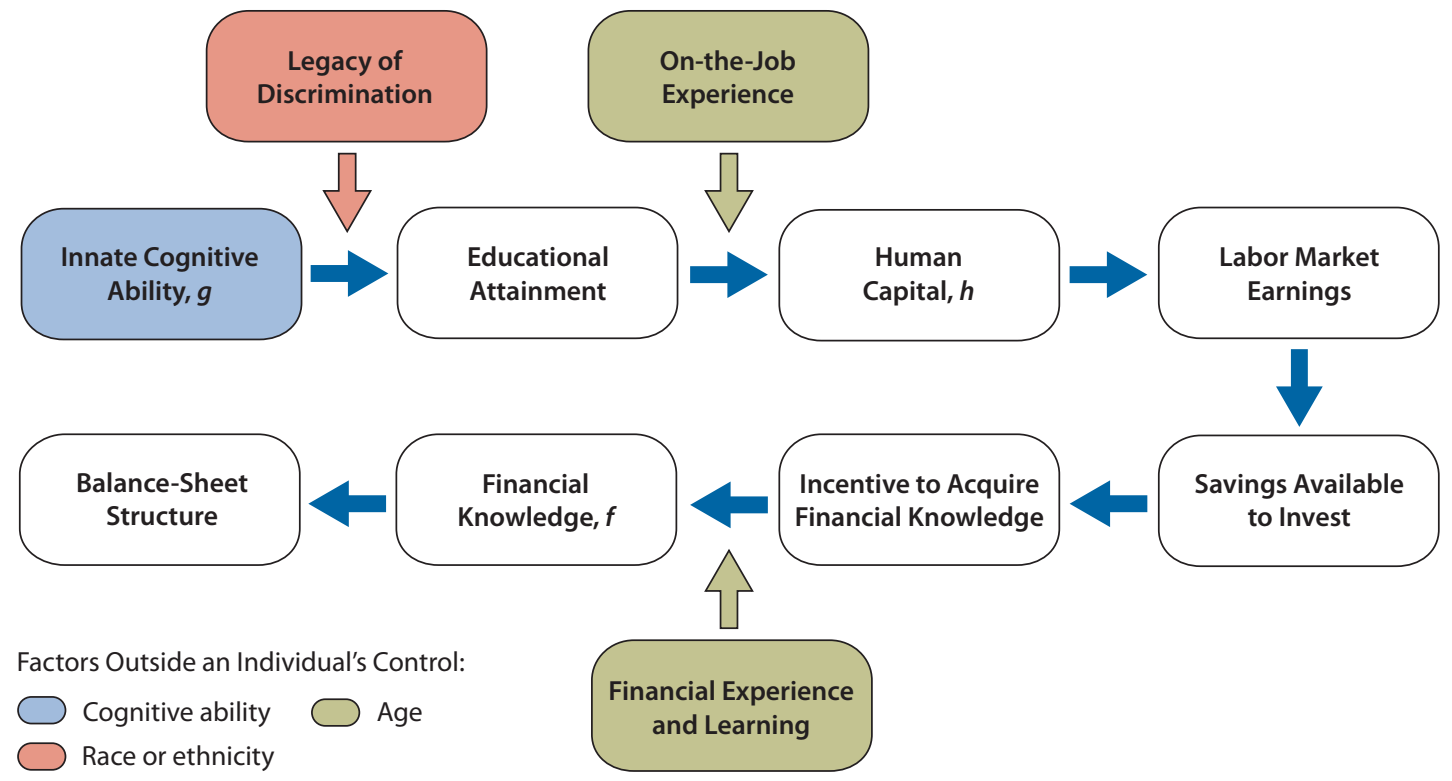

\section{A FRAMEWORK FOR UNDERSTANDING THE LINK BETWEEN ECONOMIC VULNERABILITY AND RISKY BALANCE SHEETS}

Figure 2 sketches our framework connecting a family's endowments (cognitive, social, chronological) and its economic and financial outcomes. To motivate our subsequent examination of balance sheets and net worth changes during the Great Recession, we describe in turn how educational attainment, race and/or ethnicity, and age combine to help determine earnings and influence balance-sheet choice.

\section{Variables in Explaining Financial Vulnerability}

The Role of Cognitive Ability and Educational Attainment. An individual or family head (henceforth, family) is born with some innate cognitive ability, which might be approximated by a score, $g$, on a measure of general intelligence. The family's endowment of cognitive ability is an important, but not exclusive, determinant of its educational attainment; a variety of individual and social factors also play a role.

The Role of Race and/or Ethnicity. We believe it is critical to highlight the potential importance of race and/or ethnicity in determining a family's educational attainment and all subsequent economic and financial outcomes it will experience. We summarize race- or ethnicity-based influences on educational attainment in the concept of a legacy of discrimination. Although overt discrimination in housing, education, employment, and other spheres may be less evident 
today, past discrimination and unfair treatment and access leave an unmistakable imprint on people alive today. $\frac{8}{}$

The evidence for at least a legacy of discrimination is overwhelming. The raw high school graduation rate gap between black and white men, for example, is estimated at about 15 percentage points (Murnane, 2013). Even after accounting for differences in family income, eighth-grade attendance, and the child's score on an eighth-grade mathematics test, Murnane finds that a 4.3percentage-point gap remains; and, of course, these controls themselves may embody past discrimination. The three control variables eliminate the graduation rate gap between black and white women, but they explain even less of the gaps for Hispanic men and women relative to their white counterparts. Those graduation rate gaps remain 9.1 percentage points for Hispanic men and 4.7 percentage points for Hispanic women even after controlling for family income, eighth-grade attendance, and eighth-grade math scores.

If the legacy of discrimination somehow attenuates the translation of innate cognitive ability into formal educational attainment, minority status may emerge as a significant predictor of differential economic and financial outcomes at every subsequent stage in the chain proposed in Figure 2. Not only will the fraction of people who have attained a particular degree status differ across racial and ethnic groups, but the quality of the education obtained also may differ systematically. The positive impact of on-the-job experience may be less for minorities, resulting in a smaller increment to their stock of human capital, $h$, and potential labor market earnings.

The Role of Age. Just as no one chooses one's cognitive ability or race or ethnicity, we cannot choose to be a different age than the one we are at a given time. Figure 2 suggests that age-in particular, being young-is potentially an important determinant of both economic vulnerability and financial fragility.

The upper half of Figure 2 combines job experience with innate ability and formal education and training — possibly attenuated by the legacy of discrimination — to augment a family's stock of human capital. Clearly, it takes time to acquire on-the-job experience. A younger worker has less time to build human capital and therefore may be less valuable to an employer in tough times. As shown in Figure 1, the unemployment rate among workers younger than 25 years of age remains more than double the overall rate. The unemployment rate among workers 25 to 34 years of age also is higher than for workers 35 years of age or older but is closer to the overall rate.

Age also influences a household's balance-sheet choice and is a critical determinant of outcomes (see the lower half of Figure 2). Consider first a young family with a large amount of human capital and a high income, both today and in the future. The path of this family's earnings over time is likely to be hump shaped. $\stackrel{9}{ }$ This is the result of both labor market features, including the interaction of aging with pay for performance, and social insurance arrangements (Social Security and Medicare), which entail a significant degree of progressivity. Combining these two features, workers with higher levels of human capital are more likely to have high earnings, which occurs primarily in middle age. Anticipating a subsequent decline in earnings, these workers seek to shift some of their middle-age wealth to their retirement years through private saving, pension, and insurance arrangements. The key point is that these families have relatively strong incentives to acquire financial knowledge-the stock of which we summarize as an index level, $f$ so they can shift wealth into the future efficiently. Evidence suggests that acquiring financial 


\section{Emmons and Noeth}

knowledge requires time-both to study and to learn by doing - and money. Financial planners and attorneys can be expensive, for example.

The future decline in earnings of lower-income workers is much smaller for two reasons. First, they do not receive large pay-for-performance bonuses in their peak productivity years. Second, they have less incentive to acquire financial knowledge because they will benefit from progressive social insurance schemes. If the cost of raising their stock of financial knowledge is sufficiently high, it may be rational to choose not to invest in acquiring financial knowledge.

The final link in the chain shown in Figure 2 is using financial knowledge to shape financial behavior and create a strong balance sheet. Families with high financial knowledge, who, as just discussed, are more likely to have high human capital, also are more likely to engage in sound financial decisionmaking. Such families save regularly, maintain an emergency fund of safe and liquid assets, avoid wealth-depleting financial services, choose a diversified asset mix with a relatively high risk-adjusted expected return, and use debt conservatively and for specific, investmentlike purposes such as buying a car or home or paying for a child's education. Families with low incomes are likely to have low financial knowledge and are less likely to engage in wealth-building financial behavior.

Thus, we have demonstrated that families likely to be economically vulnerable-in essence, those with relatively low levels of human capital and/or those who are young-also are likely to have poorly constructed, unnecessarily risky balance sheets because they have relatively low levels of financial knowledge. Figure 3 illustrates the "three strikes" faced by a young minority family whose head has less than a high school education. Being young means having little or no on-thejob experience and little time to have accumulated financial knowledge. Having little formal education likely means having little human capital to offer an employer, making oneself vulnerable to being laid off. In addition, a worker with poor career earnings prospects has little incentive to acquire financial knowledge. Finally, being a member of a minority means suffering from the legacies of discrimination in housing and education, which make learning more difficult and low human capital more likely with the economic and financial consequences described above. The results given this scenario include low earnings, high earnings volatility (not derived here but commonly associated with low earnings in practice), and a risky balance sheet.

Note that we do not assume any direct link between the level of cognitive ability or human capital and the efficiency of acquiring financial knowledge. In other words, even if-as we assume-increasing one's stock of financial knowledge takes the same amount of time and money, regardless of their stock of human capital, those families with higher human capital will tend to have higher financial knowledge, as described. If instead we assume that having high cognitive ability and/or high human capital makes acquiring higher financial knowledge easier, cheaper, or faster, then the link between economic vulnerability and risky balance sheets would be even stronger. In that case, families with higher human capital would have both a stronger incentive to acquire financial knowledge and a more efficient technology to do so. Families with low cognitive ability and/or low human capital would find it even more difficult to obtain financial knowledge were they so inclined to pursue it. 
Figure 3

A Young Minority Family with Less than High School Education

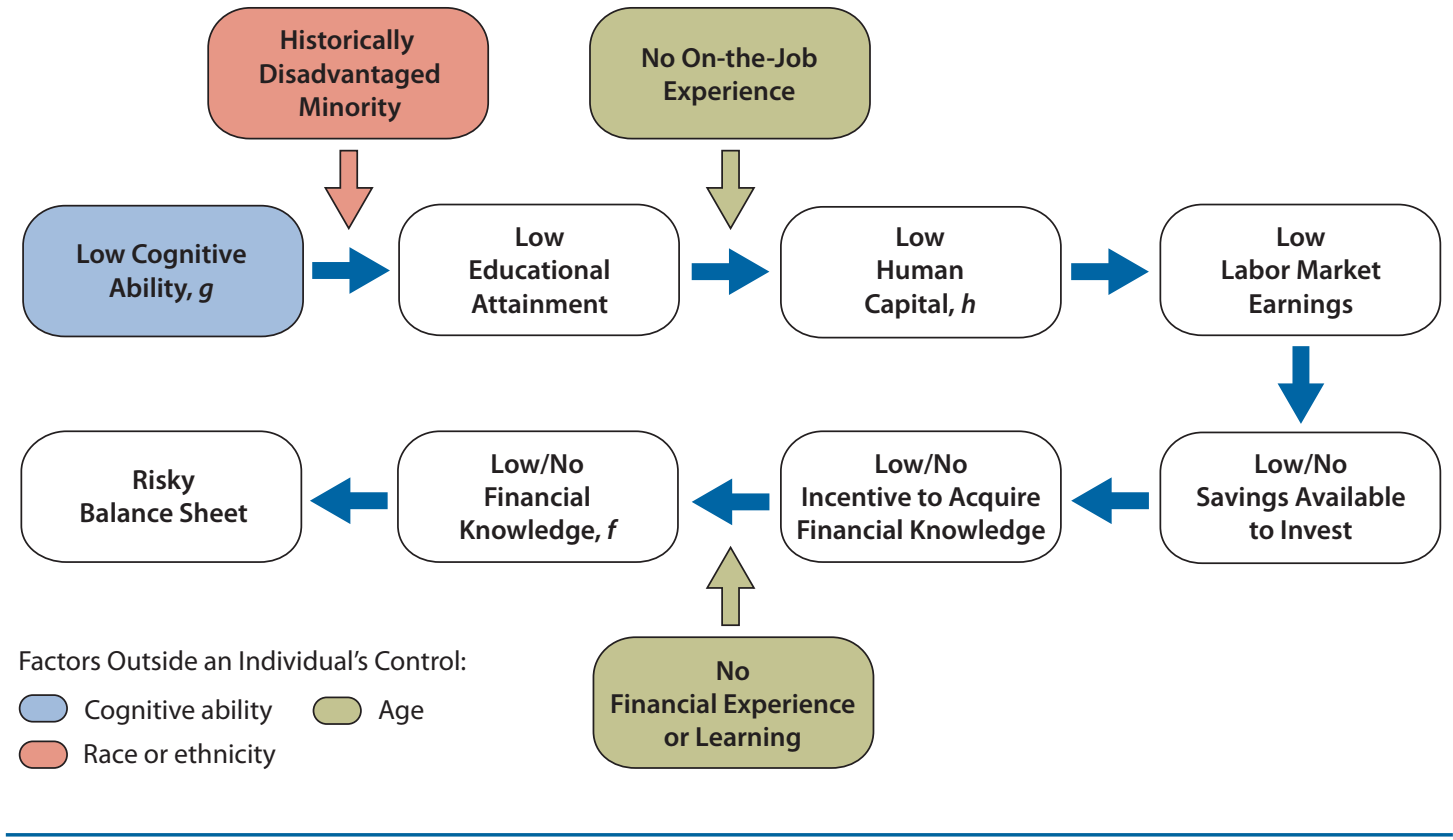

\section{PRE-CRISIS BALANCE SHEETS}

Before the crisis, young, less-educated, and minority families were known to be among the most economically vulnerable groups. Differences in financial behavior and balance-sheet composition were perhaps less well recognized or understood. We show here that economically vulnerable families generally had risky balance sheets as well.

\section{Demographically Defined Subgroups}

Data from the Survey of Consumer Finances (SCF; Board of Governors of the Federal Reserve System, various years) reveal systematic differences in the average balance-sheet composition of different family groups before the crisis. We define 18 groups based on the characteristics of the head of the household (in the case of age and educational attainment) or the person interviewed, if that is a different person (in the case of race or ethnicity), along the following dimensions:

- Age

- Family head is younger than 40 years of age (henceforth, "young");

- family head is at least 40 years old but younger than 62 years old (henceforth, "middle-aged"); or

- family head is 62 years of age or older (henceforth, "old").

- Educational attainment

- Family head has received either a two-year or a four-year college degree (henceforth, "college graduate"); 
- family head has received either a high school diploma or a General Educational Development (GED) certificate (henceforth, "high school graduate"); or

- family head has not received a college degree, high school diploma, or a GED certificate (henceforth, "high school dropout").

- Race and/or ethnicity

- Respondent is a member of an historically disadvantaged minority, in which the interviewee is black or Hispanic of any race (henceforth, "minorities"); or

- respondent is white non-Hispanic, of Asian descent, or belongs to another minority group not included elsewhere (henceforth, "nonminorities").

Safe and Liquid Assets in 2007. A basic purpose of holding assets is to provide a buffer against shocks to labor market earnings to allow smoothing of consumption spending. Indeed, precautionary saving is just as important as life cycle saving in some respects. A simple measure of the adequacy of precautionary saving is the ratio of safe and liquid assets to annual family income.

Figures 4 and 5 show the 2007 safe assets-to-income ratios among nonminority and minority families, respectively. The most obvious pattern in Figure 4 is that older nonminority families hold much larger precautionary balances than do middle-aged or, especially, young families. The second pattern is less clear: More highly educated, nonminority families generally hold more liquid assets than do less-educated families, but not in every case. The exception occurs among older high school dropout families. Overall, however, the predictions in the first section of our article are confirmed: Nonminority families who are more economically vulnerable (young and less well educated) tend to have riskier balance sheets in terms of holding lower levels of safe and liquid assets.

Figure 5 shows the 2007 ratios of safe and liquid assets to family income among minority families. The levels in Figure 5 are universally lower than those in Figure 4 for the corresponding group, confirming the prediction that the more economically vulnerable group-minoritieswould hold riskier balance sheets. Qualitatively, Figures 4 and 5 tell the same story: The greater the degree of economic vulnerability, the lower the ratio of safe and liquid assets to family income. Although is it not possible to definitively state a minimum acceptable ratio, all but 1 minority group and 5 of the 9 nonminority groups violate a commonly suggested rule of thumb to hold 6 months of income in the form of safe and liquid assets (corresponding to 50 percent in the figures).

Residential Real Estate Portfolio Shares in 2007. In principle, we could look for concentrations in any risky asset to determine portfolio diversification. Instead, we focus on housing portfolio shares. To be sure, an element of hindsight bias is involved here-we know now that housing performed particularly poorly. However, we could make the argument that concentrations in residential real estate were particularly risky because housing was a relatively poor investment from a risk/return perspective long before the crash.

Should people have known before the recent collapse of the housing market that residential real estate was a low-return, high-risk asset class over the long term? We argue that the answer is yes. Even before the housing bubble burst, historical data suggested that residential real estate generally provides moderate returns just a bit above inflation and on a par with liquid assets and 


\section{Figure 4}

Safe Liquid Assets-to-Family Income Ratio Among Whites, Asians, and Other Non-Disadvantaged Minorities (2007)

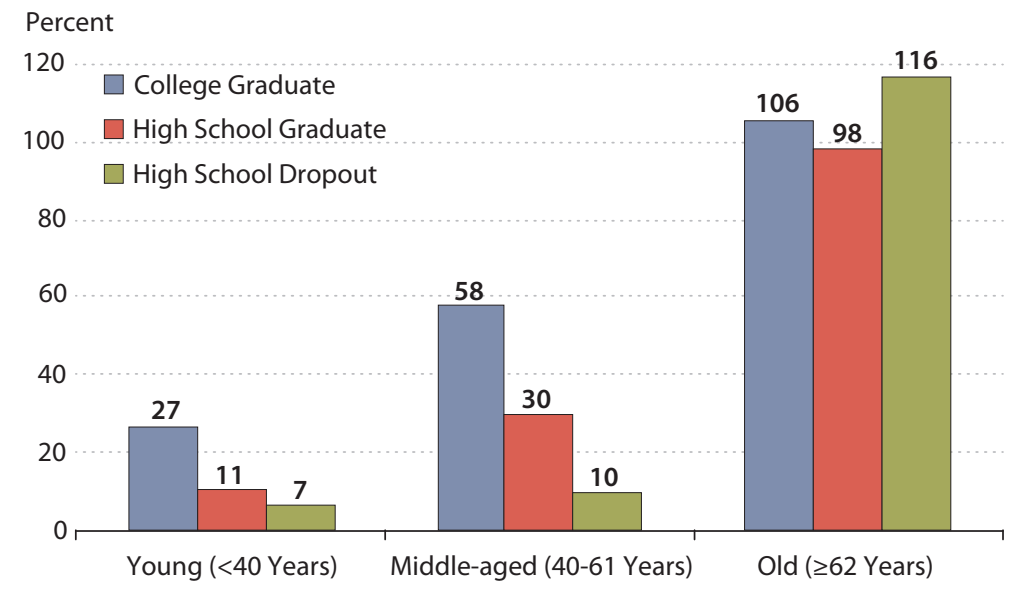

SOURCE: Board of Governors of the Federal Reserve System.

Figure 5

Safe Liquid Assets-to-Family Income Ratio Among Blacks and Hispanics (2007)

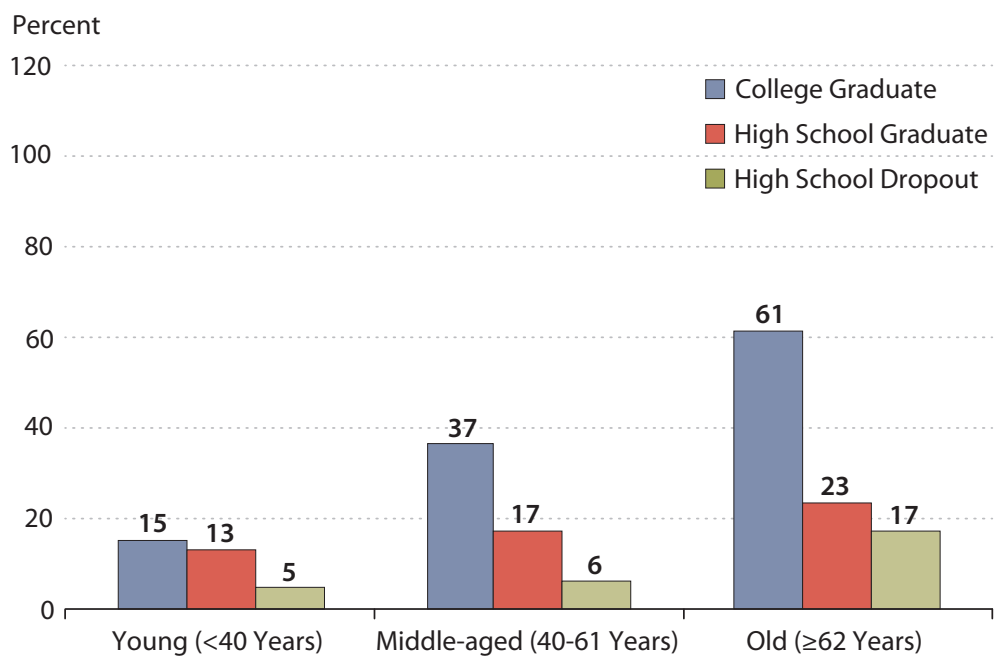

SOURCE: Board of Governors of the Federal Reserve System. 


\section{Table 1}

Rates of Return by Asset Type and Period (1983-2010)

\begin{tabular}{|c|c|c|c|c|c|c|c|c|c|c|}
\hline \multirow[b]{3}{*}{ Asset type } & \multicolumn{8}{|c|}{ Average annualized percent return (nominal terms) } & \multirow{2}{*}{\multicolumn{2}{|c|}{ Total }} \\
\hline & (1) & & (2) & & (3) & & (4) & & & \\
\hline & 1983-89 & Rank & 1989-2001 & Rank & 2001-07 & Rank & 2007-10 & Rank & 1983-2010 & Rank \\
\hline Financial assets, including stocks & 13.3 & 1 & 13.0 & 1 & 2.3 & 5 & -2.2 & 2 & 9.0 & 1 \\
\hline Pension accounts & 6.1 & 3 & 8.6 & 2 & 4.9 & 3 & -2.5 & 3 & 6.0 & 2 \\
\hline Liquid assets & 6.7 & 2 & 4.7 & 3 & 3.1 & 4 & 1.3 & 1 & 4.4 & 3 \\
\hline Business plus non-home real estate & e 3.9 & 5 & 4.1 & 5 & 9.8 & 1 & -7.3 & 5 & 4.1 & 4 \\
\hline Residential real estate & 4.0 & 4 & 4.5 & 4 & 5.8 & 2 & -7.2 & 4 & 3.4 & 5 \\
\hline Inflation (CPI-U, \%) & 3.7 & & 3.0 & & 2.7 & & 1.7 & & 3.0 & \\
\hline
\end{tabular}

SOURCE: Wolff (2012), Appendix Table 1. CPI-U, Consumer Price Index for All Urban Consumers.

Table 2

Rates of Return by Asset Type: 1983-2001 and 1983-2007

\begin{tabular}{lcccc} 
& \multicolumn{3}{c}{ Average annualized percent return (nominal terms) } \\
\cline { 2 - 4 } Asset type & $1983-2001$ & Rank & 1983-2007 & Rank \\
\hline Financial assets, including stocks & 13.1 & 1 & 10.3 & 1 \\
Pension accounts & 11.8 & 2 & 7.0 & 2 \\
Liquid assets & 4.0 & 5 & 4.8 & 4 \\
Business plus non-home real estate & 5.4 & 3 & 4.4 & 3 \\
Residential real estate & 4.3 & 4 & 3.1 & 5 \\
Inflation (CPI-U, \%) & 3.2 & & & \\
SOURCE: Authors' calculations based on Wolff (2012), Appendix Table 1. CPI-U, Consumer Price Index for All Urban \\
Consumers.
\end{tabular}

non-home real estate. Financial and pension assets have provided significantly higher returns over long periods of time. Moreover, each individual home entails significant idiosyncratic risk associated with the homeowner's region of the country, county, town, and even neighborhood.

To economists, the primary benefit of owning a home is not large capital gains but rather avoiding the risk of future rent increases and, in some places, obtaining housing services that are not readily available to rent. Housing is more like a durable good than a financial asset. $\underline{10}$

Tables 1 and 2 reproduce and extend a summary of annualized rates of return for five asset classes between 1983 and 2010, as well as during several subperiods (Wolff, 2012). The only exception to the general rule that residential real estate is a relatively low-return asset class among the periods shown here is the 2001-07 subperiod, which most now agree was a bubble. 


\section{Figure 6}

Residential Real Estate Portfolio Shares Among Whites, Asians, and Other Non-Disadvantaged Minorities (2007)

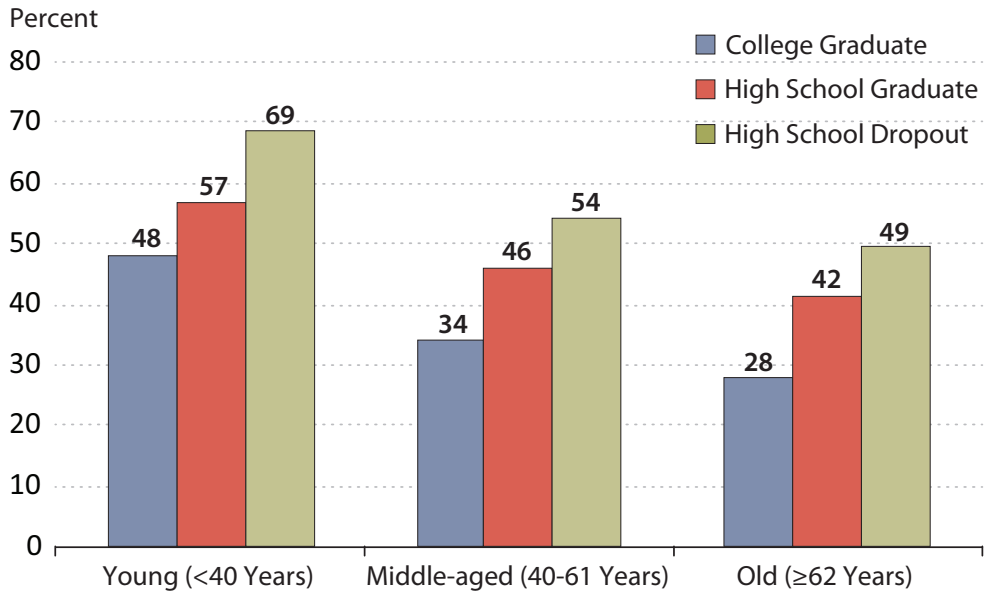

Figure 7

Residential Real Estate Portfolio Shares Among Blacks and Hispanics (2007)

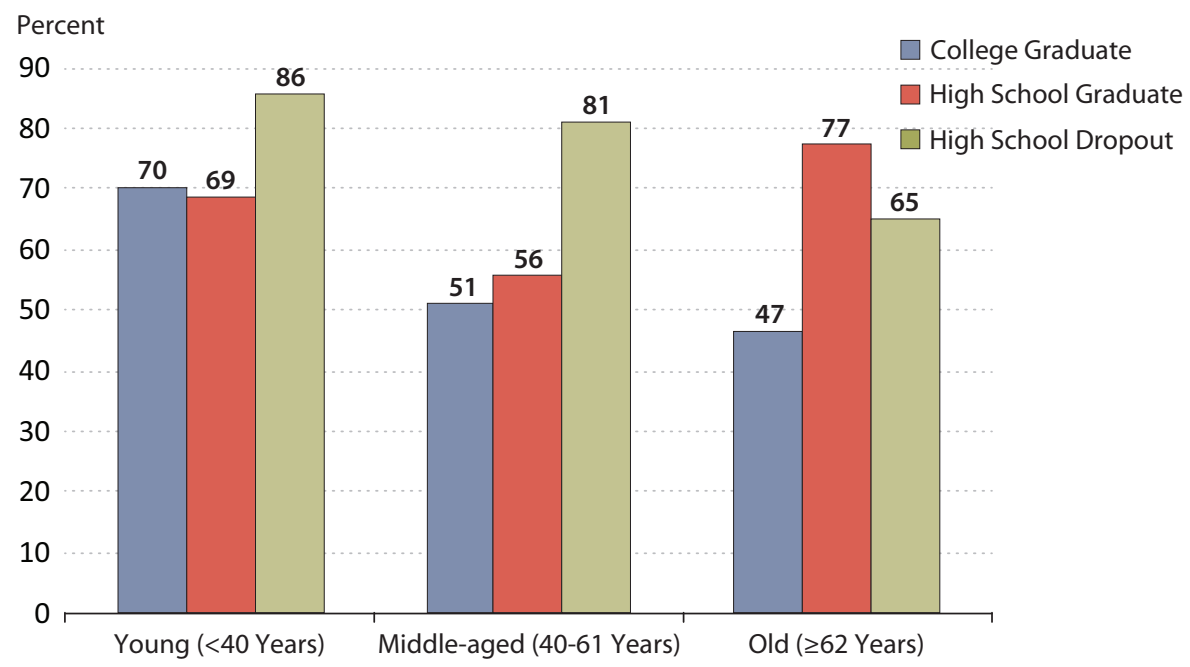

SOURCE: Board of Governors of the Federal Reserve System. 


\section{Emmons and Noeth}

Thus, people could (should) have known that housing was a low-return asset class, even if it was not well appreciated that it also was a very risky asset class. Yet, local and regional housing market downturns in recent decades had demonstrated that area-average house prices can, in fact, fall by double-digit percentages in relatively short periods of time. So, it is plausible to claim that housing was known to be-or should have been known to be-an asset class with a relatively low risk-adjusted expected return. $\frac{11}{}$

Figure 6 shows the average share of total assets held in the form of residential real estate in 2007 by each of nine nonminority subgroups. Figure 7 shows the nine minority subgroups. Among nonminority families, the pattern of asset concentration in housing along both age and educational attainment dimensions is remarkably clear. The younger the family and the lower the level of educational attainment - that is, the more economically vulnerable the family - the higher the average housing concentration. The difference in housing portfolio shares between the economically strongest subgroup (older college-educated families) and the economically weakest (young high school dropouts) is an enormous 41 percentage points, making the latter group much more vulnerable to a housing market decline. Considering that the homeownership rate in this group is considerably lower than in the former, the average real estate share in total assets is even more striking.

The pattern for average minority portfolio concentrations in housing is very similar to that for nonminorities, albeit at uniformly higher levels (see Figure 7). With a few slight exceptions, the general principles previously stated also hold here. The younger and the less-educated the family, the higher the average portfolio concentration in housing. Comparison of Figures 6 and 7 clearly shows that the third dimension of economic vulnerability-being a member of an historically disadvantaged minority-also is strongly predictive of a relatively high exposure to housing risk.

Total Debt-to-Total Assets Ratio in 2007. A high concentration in housing need not lead to financial distress in a housing market crash if the owner has sufficient net assets (including homeowner's equity) and free cash flow after debt service to meet other needs. The SCF data reveal that, rather than serving as a buffer for economically vulnerable families with high housing concentrations against a housing downturn, the liability side of their balance sheets generally tended to amplify the shocks. That is, among the subgroups considered, the economically most vulnerable have, on average, the highest concentrations in housing and the highest levels of debt, whether measured against assets or income.

Figure 8 shows that younger and less-educated nonminority families tended to have higher 2007 debt-to-assets ratios than older and better-educated families (a similar pattern existed for debt-to-income ratios; not shown). It appears that relative youth is the strongest influence on average debt ratios, while the effect of educational attainment is not as strong or clear-cut.

The dominant influence of age on balance-sheet leverage is also evident in Figure 9, which depicts debt-to-asset ratios for nine minority subgroups. Comparison of Figures 8 and 9 shows that race or ethnicity also emerges as a powerful predictor of debt ratios, as every minority subgroup has more leverage than the corresponding nonminority group. As with nonminorities, the liability side of the balance sheets for minority families tends to correlate with and amplify the effects of high housing concentrations for the most economically vulnerable subgroups. 


\section{Figure 8}

Total Debt-to-Total Assets Ratio Among Whites, Asians, and Other Non-Disadvantaged Minorities (2007)

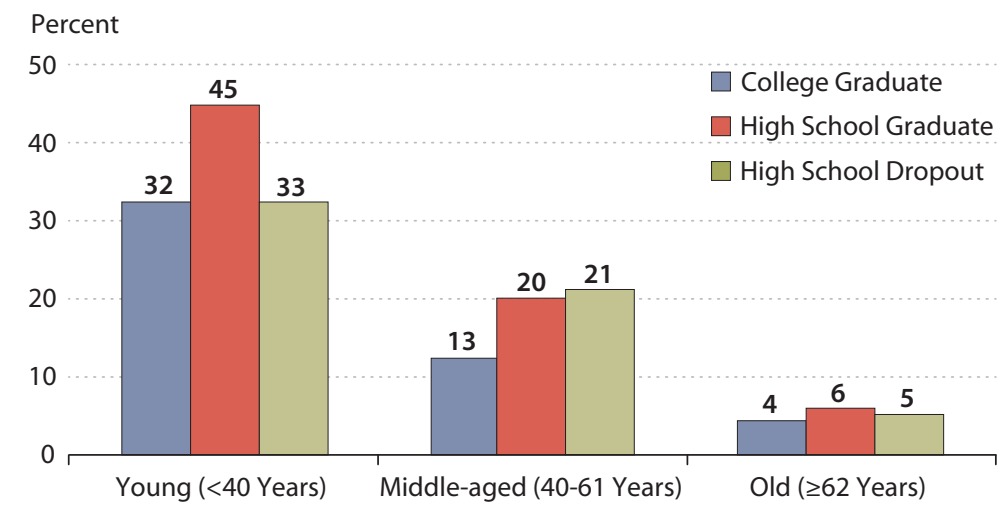

SOURCE: Board of Governors of the Federal Reserve System.

Figure 9

Total Debt-to-Total Assets Ratio Among Blacks and Hispanics (2007)

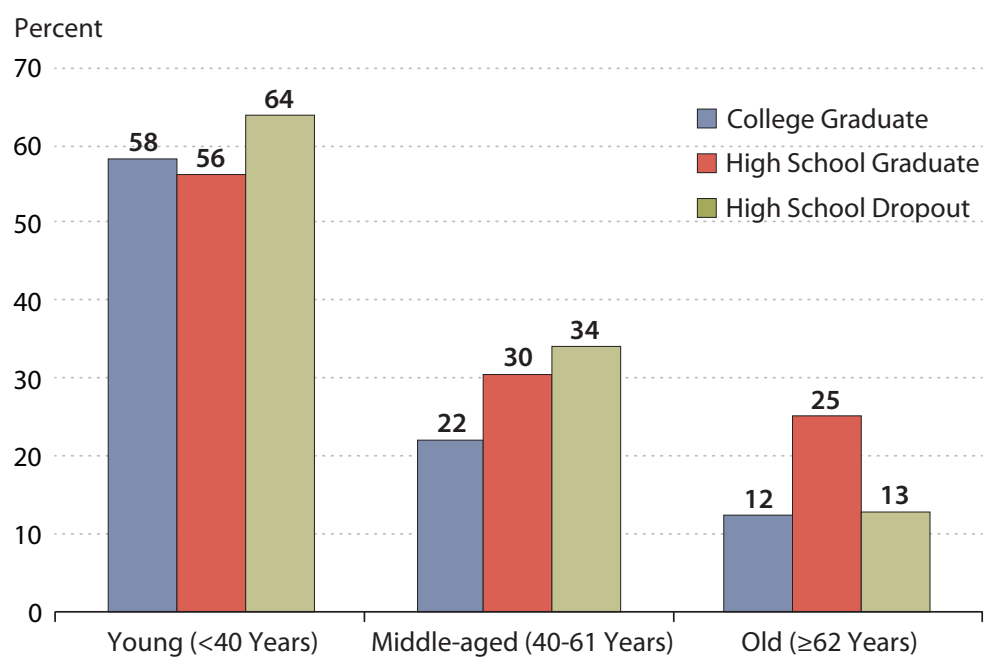

SOURCE: Board of Governors of the Federal Reserve System. 


\section{Figure 10}

Percent Decline in Mean Net Worth between the 2004-07 Average and 2010 Among Whites, Asians, and Other Non-Disadvantaged Minorities

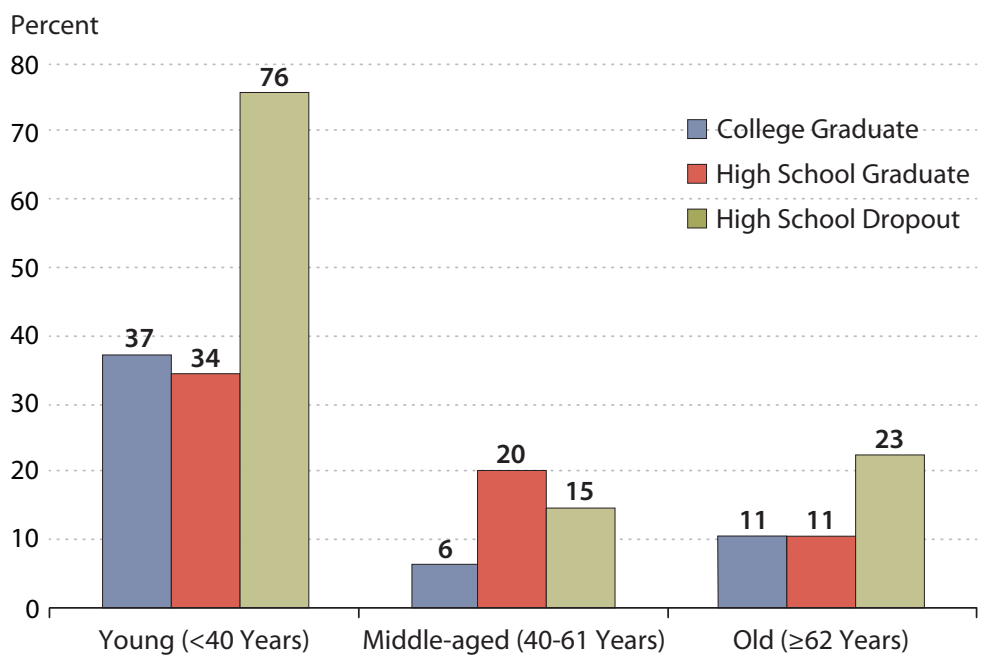

SOURCE: Board of Governors of the Federal Reserve System.

\section{WHO SUFFERED THE LARGEST PERCENTAGE DECLINES IN NET WORTH?}

Figure 10 shows that young nonminority families lost vastly more of their wealth between the 2004-07 average and the 2010 survey than middle-aged or older families $\frac{12}{2}$ across all educational attainment categories. Education levels also are important, as dropout families experienced at least twice the percentage decline in wealth compared with college graduate families in each age category.

Among minorities, age plays a strong role in wealth losses across education categories (Figure 11). Indeed, the losses suffered by young minority families were proportionally even larger compared with similarly educated older families than the same comparison among nonminority families (see Figure 10). Middle-aged minority families also fared quite poorly across all education levels. Within each age group, better-educated minority families generally lost less wealth than high school dropouts, with one glaring exception. As a group, young minority college graduates lost a staggering 76 percent of their wealth from the 2004-07 level, which was matched among the other 17 groups only by young nonminority dropout families.

2010 Leverage and Wealth Levels. How do post-crisis balance sheets look for each group? Figures 12 and 13 show that balance-sheet leverage increased during the crisis in 17 of the 18 groups (compared with Figures 8 and 9, which show the 2007 debt-to-assets ratios of nonminorities and minorities, respectively). The largest increase among nonminority families was for young high school dropouts; their debt-to-assets ratio increased from 33 percent to 63 percent. 


\section{Figure 11}

\section{Percent Decline in Mean Net Worth between the 2004-07 Average and 2010 Among Blacks and Hispanics}

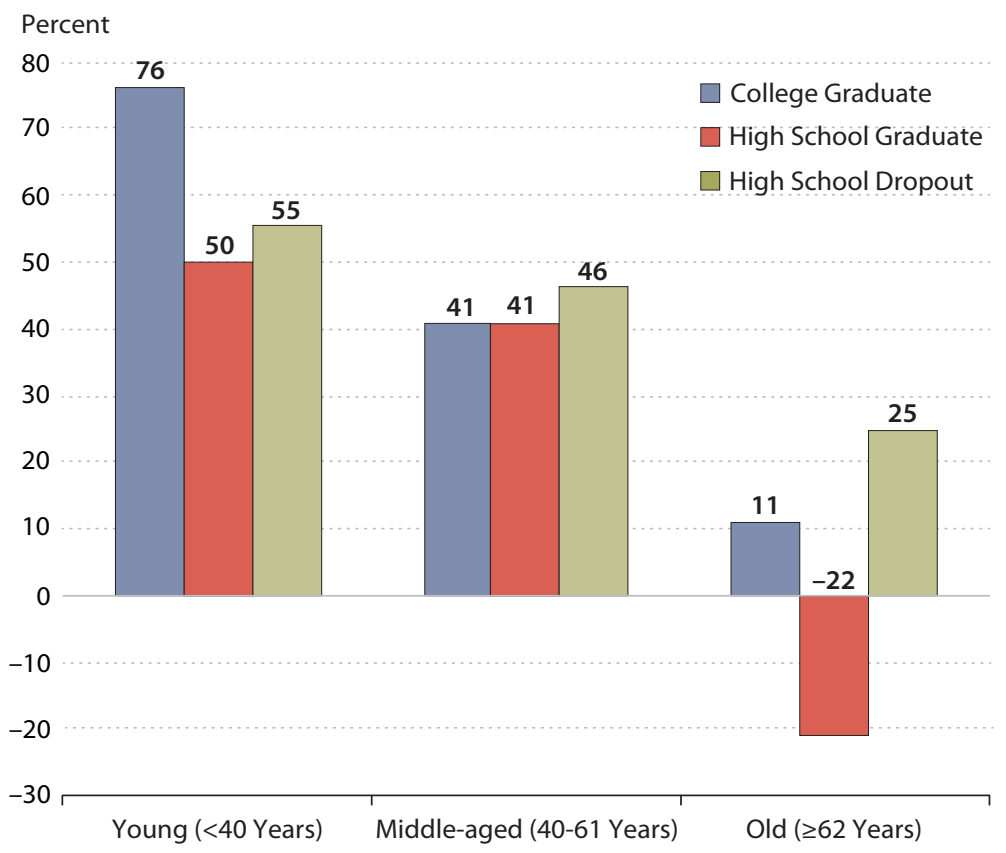

SOURCE: Board of Governors of the Federal Reserve System.

In most cases, the increases were driven primarily by falling asset values rather than increased debt.

Figure 13 presents the 2010 debt-to-assets ratios of minority groups. The only group whose ratio did not increase from 2007 was young minority dropouts; their debt-to-assets ratio declined from 64 percent to a still-high 55 percent. Looking at the assets and liabilities of this group, the best summary description of the balance-sheet changes might be "meltdown." Average total assets declined 71 percent, including an 81 percent decline in housing assets. Total liabilities decreased 74 percent, including a 78 percent decline in mortgage debt. Net worth declined 64 percent, to $\$ 10,463$.

The largest increase in the debt-to-assets ratio between 2007 and 2010 was among young minority college graduates, whose average debt-to-assets ratio increased from 58 percent to 76 percent. This group's net worth declined 66 percent from 2007, to $\$ 33,155$. Total assets decreased 40 percent, while total liabilities declined 21 percent.

Figures 14 and 15 show the 2010 levels of net worth for each of the 18 groups studied. Wealth levels vary enormously-in part because of vast differences before the crisis, but importantly, reinforced by widely disparate wealth losses during the crisis.

Figure 14 shows the 2010 family net worth among whites, Asians, and other non-disadvantaged minorities. Perhaps the most striking aspect of this figure is the stark difference between the 


\section{Emmons and Noeth}

Figure 12

Total Debt-to-Total Assets Ratio Among Whites, Asians, and Other Non-Disadvantaged Minorities (2010)

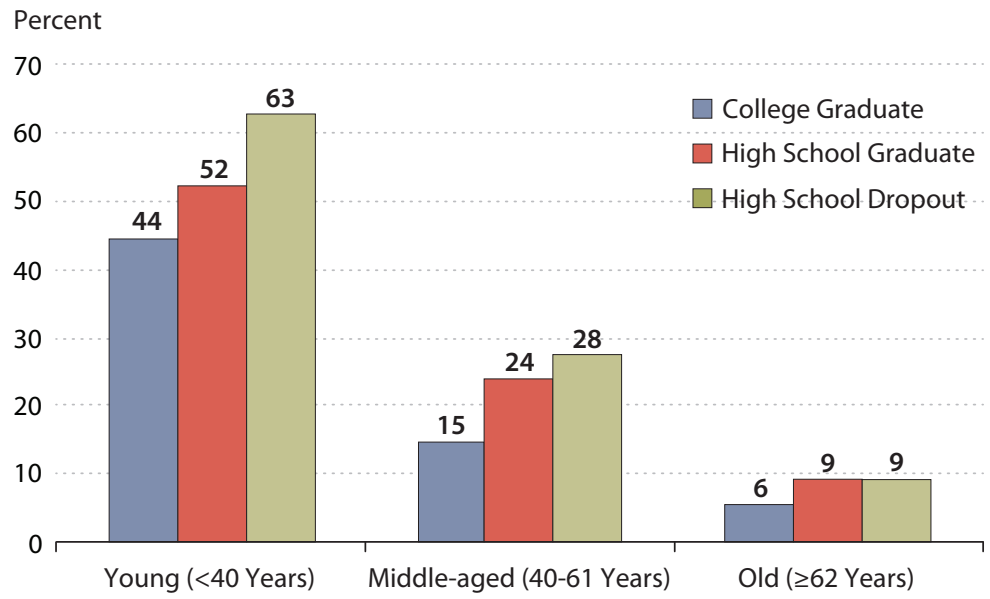

SOURCE: Board of Governors of the Federal Reserve System.

Figure 13

Total Debt-to-Total Assets Ratio Among Blacks and Hispanics (2010)

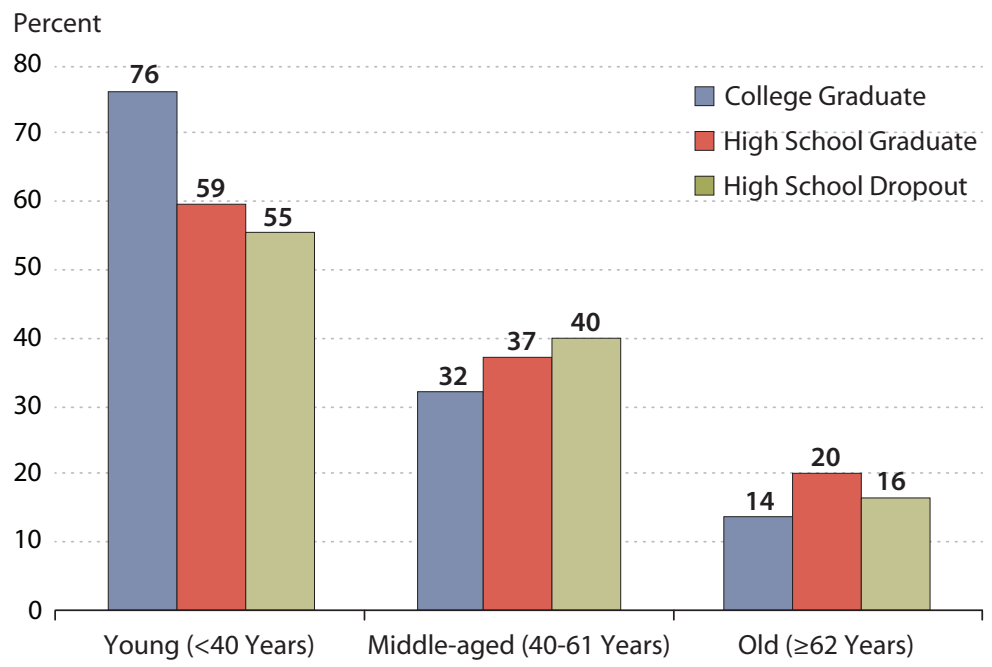

SOURCE: Board of Governors of the Federal Reserve System. 


\section{Figure 14}

Average Net Worth Among Whites, Asians, and Other Non-Disadvantaged Minorities (2010)

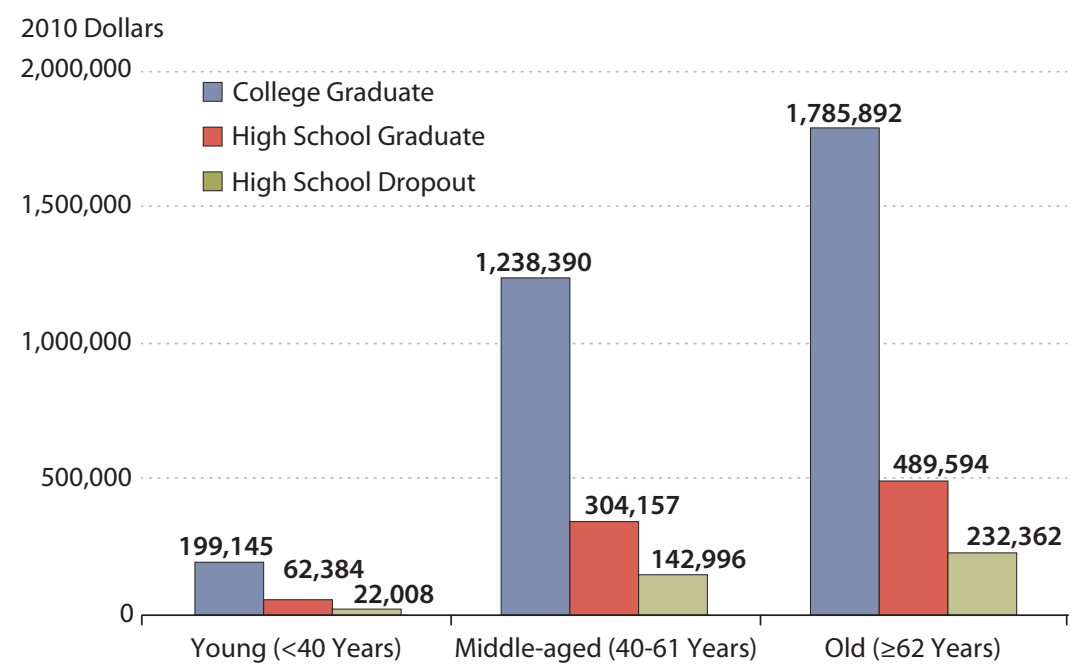

SOURCE: Board of Governors of the Federal Reserve System.

Figure 15

Average Net Worth Among Blacks and Hispanics (2010)

$\begin{aligned} 2010 \text { Dollars } & \\ \text { 2,000,000 } & \square \text { College Graduate } \\ & \square \text { High School Graduate } \\ 1,500,000 & \square \text { High School Dropout }\end{aligned}$

$1,000,000$

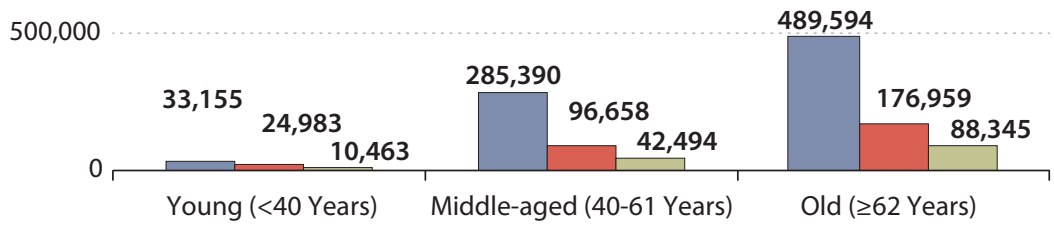

SOURCE: Board of Governors of the Federal Reserve System. 
Figure 16 Net Worth of Historically Disadvantaged Minorities as Share of Whites, Asians, and Other
Minority Counterparts (2010)

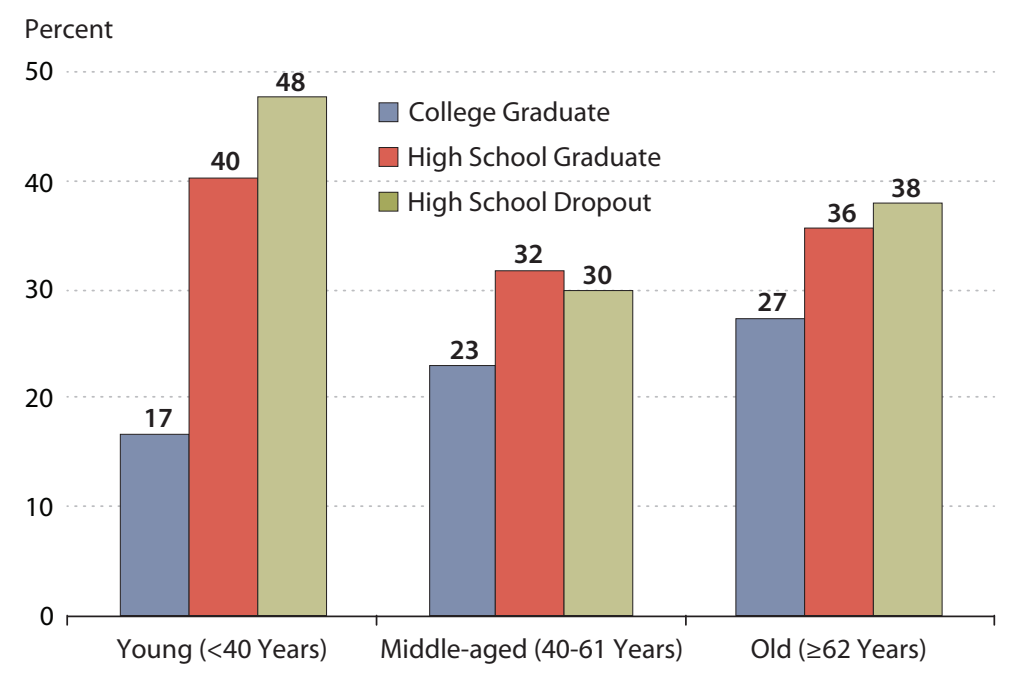

SOURCE: Board of Governors of the Federal Reserve System.

average net worth of nonminority families with college degrees and those without degrees, regardless of age. On closer inspection, the same pattern holds for high school graduates compared with high school dropouts across the life span. In other words, higher levels of educational attainment, on average, are strongly positively related to higher levels of wealth among nonminorities.

The second clear pattern in Figure 14 is that average wealth increases with age, especially between youth and middle age. Young families have average net worth that is a small fraction of the net worth of middle-aged families. Families with a household head between 40 and 61 years of age, in turn, have significantly less wealth, on average, than families with a household head 62 years or older.

Figure 15 provides the same information for minority families. Here the first strong impression is the much-lower average wealth for minorities compared with nonminorities. The same patterns connecting higher levels of education and older family heads to higher wealth also hold true among minority families.

Combining the information in the two previous figures, Figure 16 compares the 2010 average net worth of each minority family group with its nonminority counterpart. The ratio of average minority family net worth to comparable nonminority net worth ranges from a low of 17 percent among young college graduates to a high of 48 percent among young high school dropouts.

Higher educational attainment appears to be less effective in building wealth for minority families than for nonminority families, as reflected in the lower ratios in Figure 16. 


\section{Table 3}

Dependent Variable: Safe and Liquid Assets-to-Annual Family Income Ratio

\begin{tabular}{|c|c|c|c|}
\hline \multirow[b]{2}{*}{ Variable } & \multicolumn{3}{|c|}{ Regression } \\
\hline & (1) & (2) & (3) \\
\hline Intercept & $0.441^{* * *}$ & $0.490 * * *$ & $0.368^{* * *}$ \\
\hline Age $<40$ years dummy (ages 40-61 years omitted) & $-0.209 * * *$ & & $-0.162^{* * *}$ \\
\hline Age $\geq 62$ years dummy (ages 40-61 years omitted) & $0.667^{* * *}$ & & $0.662^{* * *}$ \\
\hline Less than high school education dummy (high school or GED omitted) & $-0.178^{* * *}$ & & $-0.157^{* * *}$ \\
\hline College graduate dummy (high school or GED omitted) & $0.226^{* * *}$ & & $0.188^{* * *}$ \\
\hline $\begin{array}{l}\text { Member of historically disadvantaged minority dummy } \\
\text { (white or non-disadvantaged minority omitted) }\end{array}$ & $-0.231^{* * *}$ & & $-0.198^{* * *}$ \\
\hline Married deviation & & -0.018 & $-0.055^{* * *}$ \\
\hline Number of children deviation (normalized) & & $-0.042^{* * *}$ & $-0.035^{* * *}$ \\
\hline Square root of income deviation (normalized) & & $-0.046^{* * *}$ & $-0.052^{* * *}$ \\
\hline Available credit line amount deviation (normalized) & & $0.028^{* * *}$ & $0.025^{* * *}$ \\
\hline Square root of assets deviation (normalized) & & $0.094^{* * *}$ & $0.083^{* * *}$ \\
\hline Saved within the past year dummy deviation & & $0.161^{* * *}$ & $0.148^{* * *}$ \\
\hline Emergency funds needed target deviation (normalized) & & $0.064^{* * *}$ & $0.067^{* * *}$ \\
\hline Believe you are financially lucky deviation & & $-0.110^{* * *}$ & $-0.112^{* * *}$ \\
\hline History of credit problems deviation & & $-0.173^{* * *}$ & $-0.191^{* * *}$ \\
\hline 2001 Dummy & -0.008 & 0.002 & -0.002 \\
\hline 2004 Dummy & $-0.048^{*}$ & -0.024 & -0.028 \\
\hline 2007 Dummy & $-0.073^{* * *}$ & -0.022 & $-0.056^{* *}$ \\
\hline 2010 Dummy & $-0.104^{* * *}$ & $-0.062^{* * *}$ & $-0.070^{* * * *}$ \\
\hline$R^{2}$ for first implicate & 0.1083 & 0.0735 & 0.1628 \\
\hline \multicolumn{4}{|c|}{$\begin{array}{l}\text { NOTE: Unweighted regressions using repeated-imputation inference techniques. The deviation variables are deviations from the weighted mean } \\
\text { within the smallest demographic subgroup for age, race, and education level. *, }{ }^{* *} \text {, and }{ }^{* * *} \text { indicate significance at the } 10,5 \text {, and } 1 \text { percent levels, } \\
\text { respectively. }\end{array}$} \\
\hline
\end{tabular}

\section{THE IMPORTANCE OF DEMOGRAPHIC FACTORS IN BALANCE-SHEET CHOICE}

The evidence presented previously suggests that age, educational attainment, and race or ethnicity are associated with key balance-sheet measures of risk and measures of wealth losses during the financial crisis and recession. In this section, we provide regression evidence that provides insight into the relative importance of demographic determinants of financial behavior and outcomes.

Safe and Liquid Assets. The ratio of safe and liquid assets to family income is a proxy for the size of a family's emergency fund. Table 3 displays results of three ordinary least squares regressions of a family's ratio of safe and liquid assets to family income on demographic indicator 


\section{Emmons and Noeth}

variables; a host of economic, financial, and attitudinal variables from the SCF waves of 1998 through 2010; and year dummies. Each of the second set of variables is expressed as the deviation for a particular family from the mean of the subgroup to which it belongs (i.e., one of the 18 age, education, and race or ethnicity groups).

Regression (1) uses only the demographic variables and the year dummies. Each demographic indicator variable is highly significant in the direction we expect. That is, (i) the older the family, the higher the safe assets-to-income ratio; (ii) the higher the education level, the higher the safe assets-to-income ratio; and (iii) minorities have a lower safe assets-to-income ratio than nonminorities. The coefficient estimates also suggest the differences are economically large. Compared with middle-aged families, for example, being a young family is associated with a 21-percentage-point lower safe assets-to-income ratio. Older families have a remarkable 67-percentage-point higher safe assets-to-income ratio than middle-aged families.

Similarly, the differences across education groups are economically large. High school dropouts have an 18-percentage-point lower safe assets-to-income ratio than high school graduates, while college graduates have a 23-percentage-point higher safe assets-to-income ratio than high school graduates. Minority families have a 23-percentage-point lower safe assets-to-income ratio than nonminority families. The dummy variables for 2007 and 2010 are highly significantly negative, although not particularly large, indicating that safe assets-to-income ratios were depleted both before and after the financial crisis.

Regression (2) uses a host of endogenous variables in demeaned form to capture idiosyncratic deviations of families that are not explained by our exogenous demographic variables. The idea is that, relative to the subgroup's average value on, say, the income variable-which may be determined in large part by demographic variables-a family's deviation from the average may contain information relevant to its balance-sheet behavior.

Our preferred specification is regression (3). We use the exogenous demographic variables, the demeaned endogenous variables, and the year dummies together to explain a family's safe assets-to-income ratio. The coefficients and significance levels of most of the variables from all three sets of variables survive largely intact from regressions (1) and (2). We conclude that age, educational attainment, and race or ethnicity are very strong predictors of a family's chosen safeassets-to-income ratio.

Residential Real Estate Portfolio Share. Table 4 presents the coefficient estimates from three ordinary least squares regressions of home-owning families' ratio of residential real estate to total assets on (i) demographic indicator variables, (ii) demeaned endogenous variables, and (iii) year dummy variables. Our decision to include here only regressions that include homeowners, rather than all families, represents a compromise. We would like to capture both the extensive margin of homeownership - the decision to become a homeowner-and the intensive margin - the decision of how much to spend for a home. However, both decisions are endogenous. We would need to model the two distinct decisions involved, but this is beyond the scope of our article. $\underline{13}$

We could collapse the two decisions into a single dimension, as in Figures 6 and 7. In a regression framework, however, the large number of young families with no residential real estate would dominate the results in an unweighted regression. In our view, this would inaccu- 


\section{Table 4}

\section{Dependent Variable: Residential Real Estate Assets-to-Total Assets Ratio: Homeowners Only}

\begin{tabular}{|c|c|c|c|}
\hline \multirow[b]{2}{*}{ Variable } & \multicolumn{3}{|c|}{ Regression } \\
\hline & (1) & (2) & (3) \\
\hline Intercept & $0.492^{* * *}$ & $0.511^{* * *}$ & $0.542^{* * *}$ \\
\hline Age $<40$ years dummy (ages 40-61 years omitted) & $0.138^{* * *}$ & & $0.128^{* * *}$ \\
\hline Age $\geq 62$ years dummy (ages 40-61 years omitted) & $-0.048^{* * *}$ & & $-0.035^{* * *}$ \\
\hline Less than high school education dummy (high school or GED omitted) & $0.099 * * *$ & & $0.092 * * *$ \\
\hline College graduate dummy (high school or GED omitted) & $-0.146^{* * *}$ & & $-0.130^{* * *}$ \\
\hline $\begin{array}{l}\text { Member of historically disadvantaged minority dummy } \\
\text { (white or non-disadvantaged minority omitted) }\end{array}$ & $0.146^{* * *}$ & & $0.135^{* * *}$ \\
\hline Married deviation & & $-0.057^{* * *}$ & $-0.060^{* * *}$ \\
\hline Number of children deviation (normalized) & & $0.013^{* * *}$ & $0.009^{* * *}$ \\
\hline Square root of income deviation (normalized) & & $-0.019^{* * *}$ & $-0.016^{* * *}$ \\
\hline Available credit line amount deviation (normalized) & & $-0.008^{* * *}$ & $-0.018^{* * *}$ \\
\hline Saved within the past year dummy deviation & & $-0.096^{* * *}$ & $-0.094^{* * *}$ \\
\hline Emergency funds needed target deviation (normalized) & & $-0.005^{* * *}$ & $-0.004^{* * *}$ \\
\hline Believe you are financially lucky deviation & & $0.044 * * *$ & $0.049 * * *$ \\
\hline History of credit problems deviation & & $0.047^{* * *}$ & $0.042^{* * *}$ \\
\hline 2001 Dummy & -0.001 & -0.010 & -0.006 \\
\hline 2004 Dummy & $0.049^{* * *}$ & $0.047^{* * *}$ & $0.053^{* * *}$ \\
\hline 2007 Dummy & $0.057^{* * *}$ & $0.050^{* * *}$ & $0.059 * * *$ \\
\hline 2010 Dummy & $0.079 * * *$ & $0.061^{* * *}$ & $0.065^{* * *}$ \\
\hline$R^{2}$ for first implicate & 0.1267 & 0.1321 & 0.2292 \\
\hline
\end{tabular}

NOTE: Unweighted regressions using repeated-imputation inference techniques. The deviation variables are deviations from the weighted mean within the smallest demographic subgroup for age, race, and education level. *** indicates significance at the 1 percent level.

rately suggest that young families behave very conservatively in their housing decisions. To be sure, some do; but many do not. On the other hand, in a regression weighted by a family's housing assets, total assets, or other dollar measure, relatively few families could unduly influence the results we ascribe to young families overall. We adopt a compromise position involving unweighted regressions among home-owning families alone.

Once again, regression (1) suggests that demographic variables predict housing portfolio shares-conditional on being a homeowner-in the expected directions. There is strong evidence of a time trend, with increasing housing shares from 2004 onward. Regression (2) shows results using only the demeaned endogenous variables and year dummies, while regression (3) combines all three sets of variables.

The coefficient estimates from our preferred specification, regression (3), suggest that, after controlling for idiosyncratic factors and time effects, being young is associated with a 13percentage-point higher housing portfolio share than among middle-aged families, who, in turn, 


\section{Emmons and Noeth}

\section{Table 5}

\section{Dependent Variable: Total Debt-to-Total Assets Ratio}

\begin{tabular}{|c|c|c|c|}
\hline \multirow[b]{2}{*}{ Variable } & \multicolumn{3}{|c|}{ Regression } \\
\hline & (1) & (2) & (3) \\
\hline Intercept & $0.275^{* * *}$ & $0.350^{* * *}$ & $0.306^{* * *}$ \\
\hline Age $<40$ years dummy (ages $40-61$ omitted) & $0.343^{* * *}$ & & $0.322^{* * *}$ \\
\hline Age $\geq 62$ years dummy (ages $40-61$ omitted) & $-0.180^{* * *}$ & & $-0.178^{* * *}$ \\
\hline Less than high school dummy (high school or GED omitted) & $-0.037^{* *}$ & & $-0.043^{* * *}$ \\
\hline College graduate dummy (high school or GED omitted) & $-0.061^{* * *}$ & & $-0.037^{* * *}$ \\
\hline $\begin{array}{l}\text { Member of historically disadvantaged minority dummy } \\
\text { (white or non-disadvantaged minority omitted) }\end{array}$ & $0.080^{* * *}$ & & $0.067^{* * *}$ \\
\hline Married deviation & & $-0.072^{* * *}$ & $-0.056^{* * *}$ \\
\hline Number of children deviation (normalized) & & 0.002 & -0.001 \\
\hline Square root of income deviation (normalized) & & $-0.013^{* * *}$ & $-0.007^{* * *}$ \\
\hline Available credit line amount deviation (normalized) & & $0.018^{* * *}$ & $0.020^{* * *}$ \\
\hline Saved within the past year dummy deviation & & $-0.141^{* * *}$ & $-0.135^{* * *}$ \\
\hline Emergency funds needed target deviation (normalized) & & $-0.007^{* *}$ & $-0.006^{*}$ \\
\hline Believe you are financially lucky deviation & & $0.139 * * *$ & $0.136^{* * *}$ \\
\hline History of credit problems deviation & & $0.232^{* * *}$ & $0.235^{* * *}$ \\
\hline 2001 Dummy & -0.016 & $-0.030^{* *}$ & -0.021 \\
\hline 2004 Dummy & 0.025 & 0.014 & 0.023 \\
\hline 2007 Dummy & $0.039^{* *}$ & 0.021 & $0.040^{* * *}$ \\
\hline 2010 Dummy & $0.104^{* * *}$ & $0.082^{* * *}$ & $0.091^{* * *}$ \\
\hline$R^{2}$ for first implicate & 0.0868 & 0.0675 & 0.1386 \\
\hline
\end{tabular}

have housing shares about 3.5 percentage points higher than older families. High school dropouts have housing portfolio shares 9 percentage points higher than high school graduates, who have housing shares 13 percentage points higher than college graduates. Finally, minorities have housing portfolio shares about 14 percentage points higher than nonminorities, after controlling for idiosyncratic and time effects.

\section{Balance-Sheet Leverage}

Table 5 shows the coefficient estimates from three ordinary least squares regressions of a family's total debt-to-total assets ratio on demographic indicator variables, demeaned endogenous variables, and year dummy variables. As before, regression (1) suggests that demographic variables are powerful predictors of balance-sheet leverage, although the relationship between educational attainment and leverage may be nonlinear. The years 2007 and 2010 appear to dif- 
fer from earlier years, suggesting a time trend. Regression (2) shows results using only the demeaned endogenous variables and year dummies, while regression (3) combines all three sets of variables.

The coefficient estimates from our preferred specification, regression (3), suggest that age is a strong predictor of balance-sheet leverage. Being young is associated with a 32-percentagepoint higher debt-to-assets ratio than being middle-aged, which, in turn, is associated with an 18-percentage-point higher ratio than among older families. The effect of educational attainment appears to be nonlinear. High school graduates have the highest debt-to-assets ratios, while both high school dropouts and college graduates have lower ratios, after controlling for idiosyncratic and time effects. The size of these effects is not large, however. Finally, controlling for other factors, minorities have 6-percentage-point higher debt-to-asset ratios than nonminorities.

\section{INTERVENTIONS TO BREAK THE LINK BETWEEN ECONOMIC VULNERABILITY AND RISKY BALANCE SHEETS}

Using the Federal Reserve's SCF, we found that several groups of economically vulnerable families entered the recession with risky balance sheets; they held low levels of emergency savings, were highly concentrated in housing, and carried a heavy debt burden. These same families, on average, generally suffered the largest percentage decreases in wealth. A decade or more of financial innovation and liberalization may have been a factor increasing the riskiness of many of these families' balance sheets, as greater amounts of credit were available to more people than ever before. Economically vulnerable families may have been more susceptible to the "siren songs" of homeownership and easy credit in part because of low levels of financial knowledge or sophistication.

Can the link between economic vulnerability and risky balance sheets be broken? In the following discussion, we briefly illustrate where several types of interventions fit into our schematic of the determination of earnings, financial knowledge, and financial behavior. Our general conclusion is that the earlier in the chain of causation the intervention occurs, the more likely it is to be effective.

\section{Policy Interventions}

Financial Literacy Training. It seems the most direct response to evidence of poor financial decisionmaking is to provide financial literacy training. As Figure 17 clearly shows, however, such an intervention may be "too little, too late." The fundamental determinants of financial knowledge, as we have argued, include human capital and its determinants, as well as the incentives to become financially knowledgeable. Financial literacy training of low-income adults, for example, may yield modest results.

In-Kind or Cash Benefits. If low incomes are the reason families do not save-which, in turn, reduces the incentive to become financially knowledgeable - then we could seek to raise families' incomes. However, there is no automatic link between higher income and higher saving, and the amounts of likely transfers may not remove the most important aspects of the "poverty 


\section{Emmons and Noeth}

\section{Figure 17}

\section{Intervention Strategy: Financial Literacy Training}

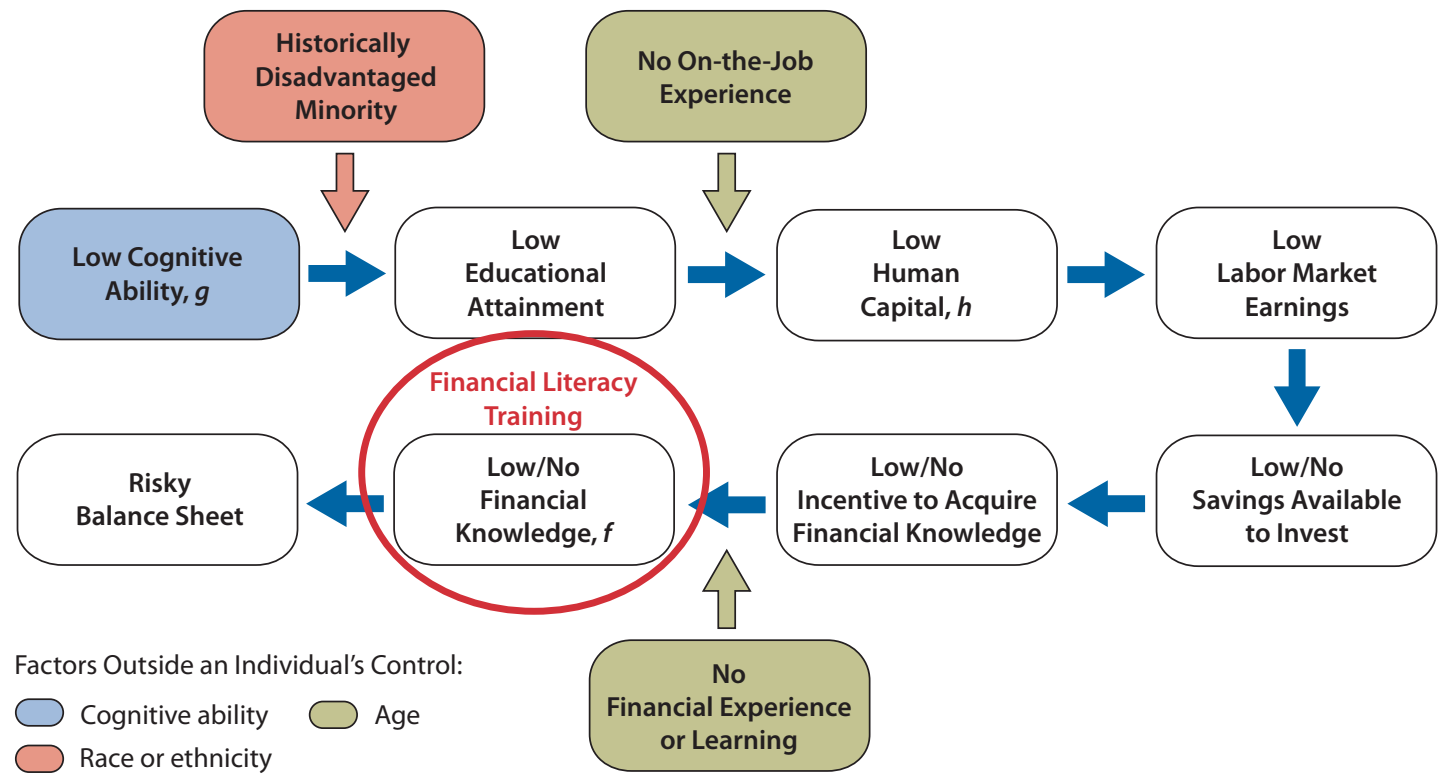

Figure 18

Intervention Strategy: Redistribution in Cash or In-Kind

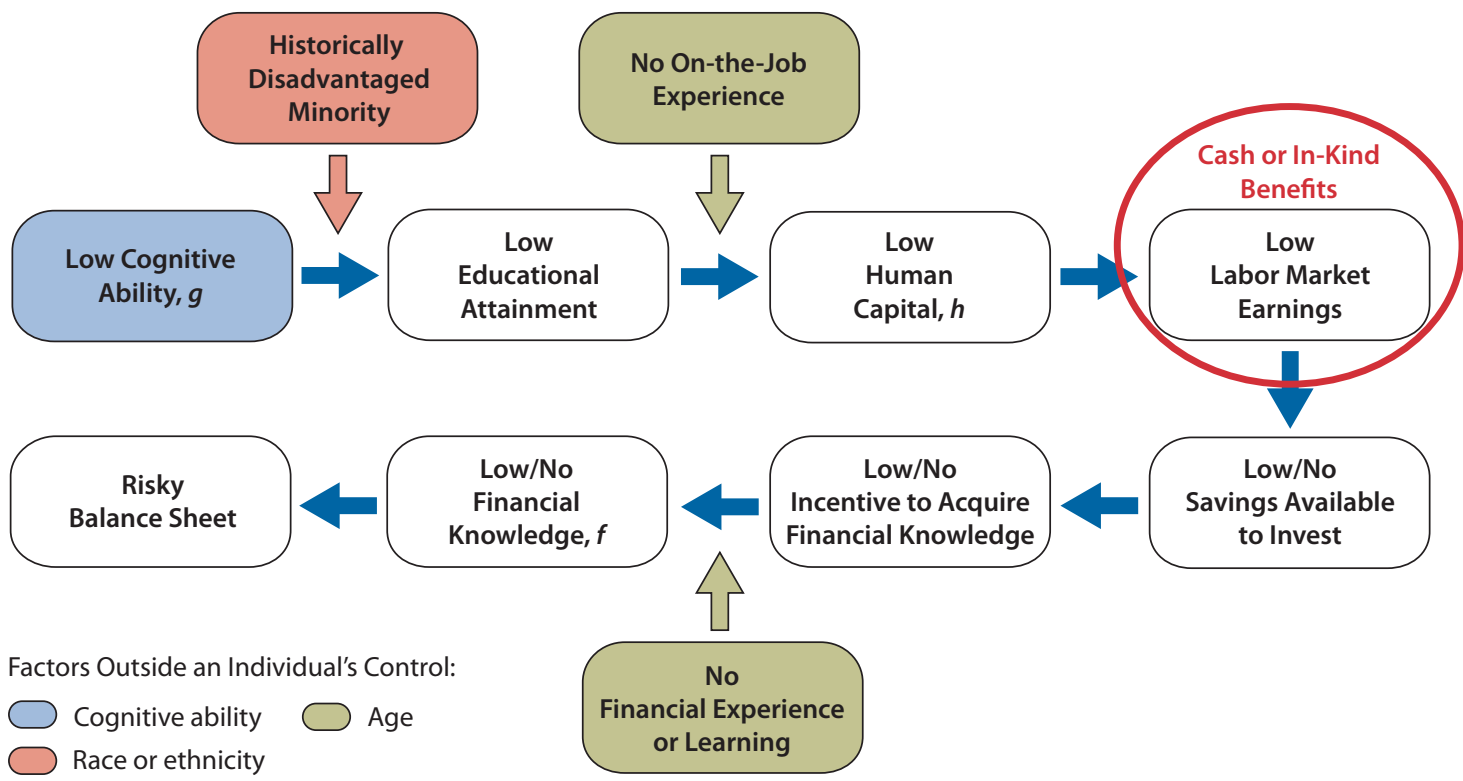


Figure 19

Intervention Strategy: Individual Development Accounts

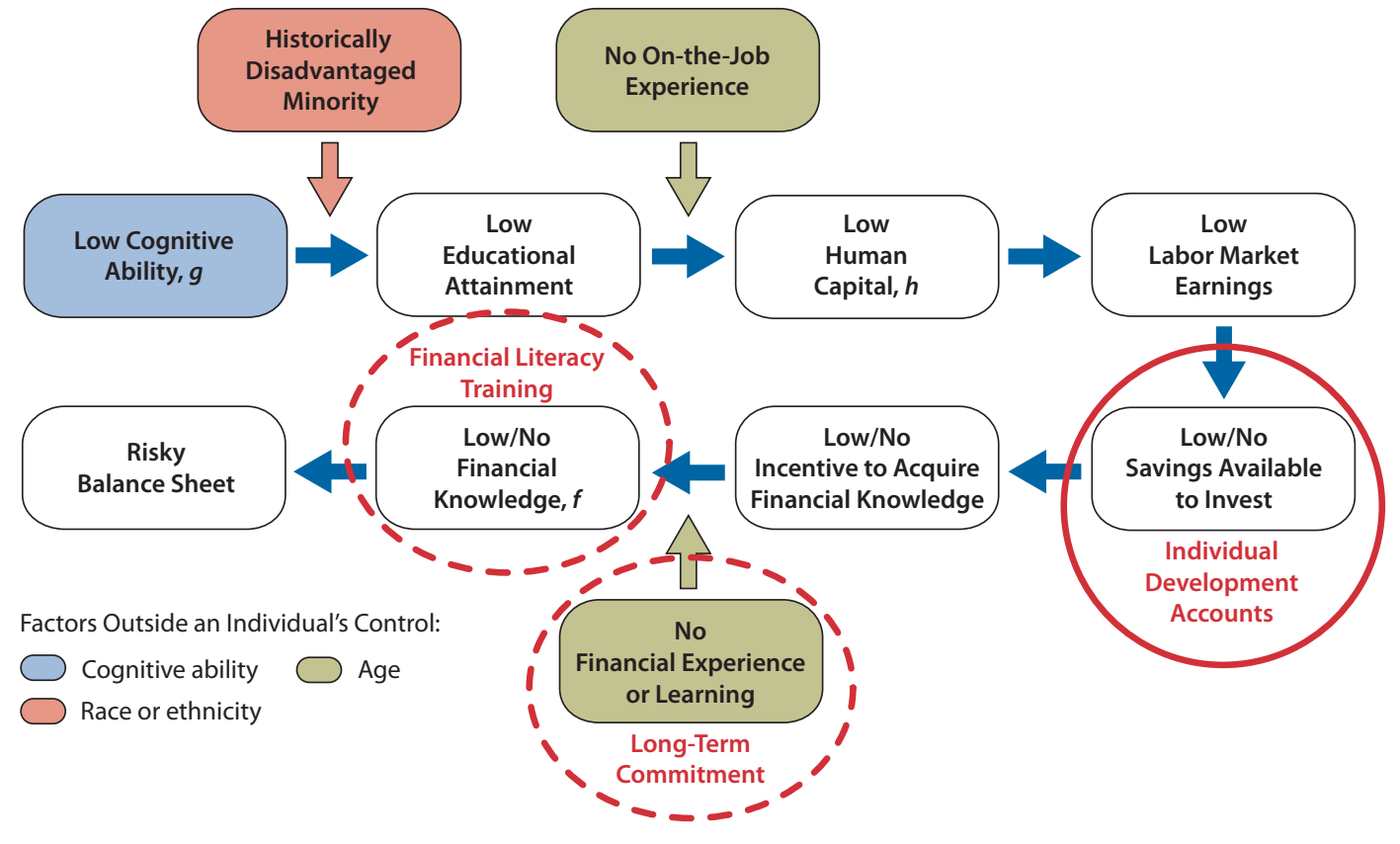

Figure 20

Intervention Strategy: Early Childhood Enrichment

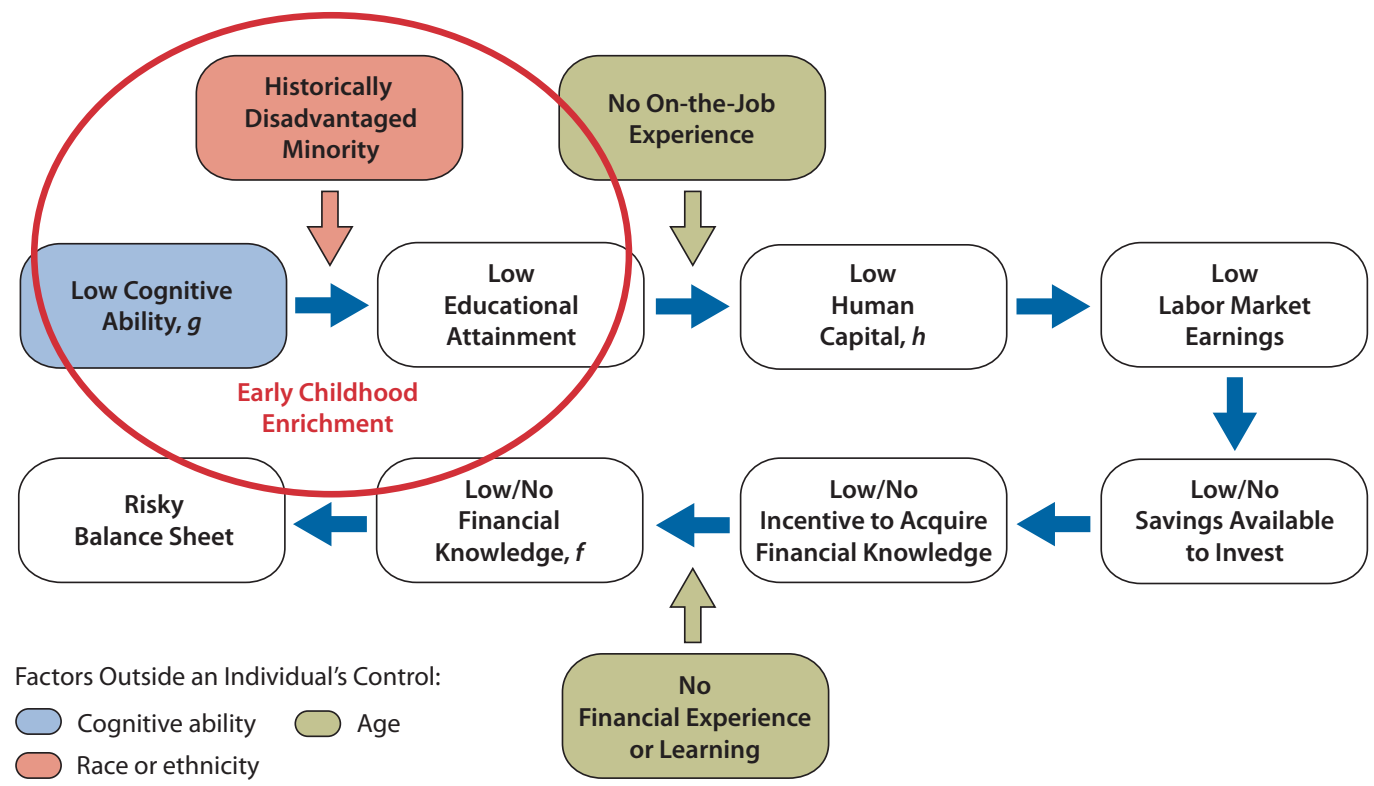




\section{Emmons and Noeth}

trap" created by means-tested benefits and progressive social insurance. Thus, there is no compelling reason to believe that benefits targeted at low-income families would translate reliably into greater financial knowledge (Figure 18).

Individual Development Accounts (IDAs). IDAs combine saving subsidies with financial literacy training and, importantly, a long-term commitment by the participant to achieve a savings goal. As Figure 19 suggests, IDAs combine interventions at several stages in the financial behavior process. They do not necessarily affect human capital, which we have suggested is a key determinant of financial behavior and ultimate financial outcomes.

Early Childhood Intervention. The most effective interventions are likely to occur during the very early stages in an individual's life because human capital is a key to both economic and financial success and stability (Figure 20). These early interventions could include health, nutrition, or educational enrichment; savings accounts; or even financial education if it is properly designed.

\section{CONCLUSION}

Many factors, including low human capital and lack of financial knowledge and experience, combined to create very risky balance sheets for economically vulnerable families before the recent financial crisis. The balance sheets of such families typically had low levels of liquid assets, high portfolio concentrations in housing, and relatively high leverage. The families hardest hit by the recession tended to be young, those without college degrees, and/or members of historically disadvantaged minorities. Unemployment rates among all these groups increased sharply and remain elevated well into the recovery; thus, the affected families are both economically vulnerable and financially fragile.

We provide a framework to better understand why so many economically vulnerable families entered the recession with very risky balance sheets. We use SCF data to define 18 groups based on the characteristics of the head of the household or the person interviewed along the following dimensions: age, educational attainment, and race and/or ethnicity.

We discuss examples of interventions that may help break the link between economic vulnerability and risky balance sheets-specifically, financial literacy training, in-kind or cash benefits, Individual Development Accounts, and early childhood intervention. Our general conclusion is that the earlier in the chain of causation the intervention occurs, the more likely it is to be effective. 


\section{NOTES}

1 Hoynes et al. (2012) find that men, blacks, Hispanics, young people (especially under 25 years of age), and those with low levels of education incurred the most job market dislocations during the recent recession. These patterns were virtually unchanged from previous recessions at least as far back as 1979. The proximate cause of extreme cyclical sensitivity of workers with these demographic characteristics was the mix of industries and occupations in which they tend to engage, including construction and manufacturing sectors and associated job categories.

2 Data are from the Federal Reserve's Survey of Consumer Finances (SCF; Board of Governors of the Federal Reserve System, various years) and are adjusted for inflation.

3 According to the SCF, the average inflation-adjusted wealth loss among all families between 2007 and 2010 was 15 percent. The median loss was 39 percent; see Emmons and Noeth (2012) and Bricker et al. (2012).

4 Hur (2012) provides evidence of large losses of labor income and net wealth in addition to declines in consumption among young families during the recession.

5 A large finance literature explores the trade-off between income risk and portfolio risk. Heaton and Lucas (2000) find that households with high and variable business income hold less wealth in stocks than other similarly wealthy households. Similarly, holding stock in the firm where one works reduces the portfolio share of other common stocks for non-entrepreneurs.

6 See Dynan, Skinner, and Zeldes (2004).

7 For example, only 49 percent of young high school dropout minority individuals or families reported saving anything in the year before being surveyed in 2007 for the SCF. Only 40 percent of young high school dropout nonminority households saved. The population average was 56 percent. Carroll, Dynan, and Krane (2003) find that families with low levels of permanent income do not vary their precautionary wealth with their idiosyncratic risk of becoming unemployed, while moderate- and higher-income families do.

8 There is strong evidence that actual discrimination continues today. For example, Bertrand and Mullainathan (2004) provide evidence of labor market discrimination against black job applicants. A legacy of discrimination includes poor primary and secondary school quality for many black children, who then fare much worse when they pursue higher education (Arcidiacono and Koedel, 2013).

$\underline{9}$ The discussion in this section follows the arguments in Lusardi, Michaud, and Mitchell (2013).

10 More specifically, a house is a long-lived durable good that requires substantial maintenance and tax payments; the land on which it sits is an investment asset that tends to appreciate at about the rate of overall economic growth in its region. The low overall return on housing thus is a composite return blending the declining value of the structure and the slowly appreciating value of the land underneath it.

11 Another piece of suggestive evidence pointing toward this judgment is that, when all families in the SCF are ranked from lowest to highest net worth, the housing share of assets declines nearly monotonically toward zero. In other words, housing plays a vanishingly small role in the portfolios of the wealthiest—and presumably financially savviestfamilies. The same is true of balance-sheet leverage: It declines toward zero as wealth increases in the cross section.

12 The reason for computing the change from the average of 2004 and 2007, rather than simply 2007, is that five of the 18 groups considered had higher average inflation-adjusted net worth in 2004 than in 2007. Note also that all major national house price indexes peaked in 2006 in inflation-adjusted terms.

13 Emmons and Noeth (2013) provide a detailed discussion of homeownership across age groups.

\section{REFERENCES}

Arcidiacono, Peter and Koedel, Cory. "Race and College Success: Evidence from Missouri." NBER Working Paper No. 19188, National Bureau of Economic Research, June 2013; http://www.nber.org/papers/w19188.pdf?new window=1.

Bertrand, Marianne and Mullainathan, Sendhil. "Are Emily and Greg More Employable than Lakisha and Jamal? A Field Experiment on Labor Market Discrimination." American Economic Review, September 2004, 94(4), pp. 991-1013.

Board of Governors of the Federal Reserve System. "Survey of Consumer Finances" (various years); http://www.federalreserve.gov/econresdata/scf/scfindex.htm. 


\section{Emmons and Noeth}

Bricker, Jesse; Kennickell, Arthur B; Moore, Kevin B. and Sabelhaus, John. "Changes in U.S. Family Finances from 2007 to 2010: Evidence from the Survey of Consumer Finances." Federal Reserve Bulletin, June 2012, 98(2), pp. 1-80; http://www.federalreserve.gov/pubs/bulletin/2012/pdf/scf12.pdf.

Bureau of Labor Statistics. "Unemployment Rates." http://research.stlouisfed.org/fred2/categories/32447.

Carroll, Christopher D.; Dynan, Karen D. and Krane, Spencer D. “Unemployment Risk and Precautionary Wealth: Evidence from Households' Balance Sheets." Review of Economics and Statistics, August 2003, 85(3), pp. 586-604.

Dynan, Karen E.; Skinner, Jonathan S. and Zeldes, Stephen P. "Do the Rich Save More?" Journal of Political Economy, April 2004, 112(2), pp. 397-444.

Emmons, William and Noeth, Bryan. "Household Financial Stability: Who Suffered the Most from the Crisis?" Federal Reserve Bank of St. Louis Regional Economist, July 2012, pp. 11-17; http://www.stlouisfed.org/publications/pub assets/pdf/re/2012/c/financial stability.pdf.

Emmons, William and Noeth, Bryan. "Why Did Young Families Lose So Much Wealth During the Crisis? The Role of Homeownership." Federal Reserve Bank of St. Louis Review, January/February 2013, 95(1), pp. 1-26; http://research.stlouisfed.org/publications/review/13/01/Emmons.pdf.

Heaton, John and Lucas, Deborah. "Portfolio Choices and Asset Prices: The Importance of Entrepreneurial Risk." Journal of Finance, June 2000, 55(3), pp. 1163-98.

Hoynes, Hilary W.; Miller, Douglas L. and Schaller, Jessamyn. “Who Suffers During Recessions?” NBER Working Paper No. 17951, National Bureau of Economic Research, March 2012; http://www.nber.org/papers/w17951.pdf?new window=1.

Hur, Sewon. "The Lost Generation of the Great Recession." Working paper, University of Pittsburgh, February 2013; http://www.pitt.edu/ sewonhur/papers/Hur2012.pdf.

Lusardi, Annamaria; Michaud, Pierre-Carl and Mitchell, Olivia S. "Optimal Financial Knowledge and Wealth Inequality." NBER Working Paper No. 18669, National Bureau of Economic Research, January 2013; http://www.nber.org/papers/w18669.pdf?new window=1.

Murnane, Richard J. “U.S. High School Graduation Rates: Patterns and Explanations." NBER Working Paper No. 18701, National Bureau of Economic Research, January 2013; http://www.nber.org/papers/w18701.pdf?new_window=1.

Wolff, Edward N. "The Asset Price Meltdown and the Wealth of the Middle Class." NBER Working Paper No. 18559, National Bureau of Economic Research, November 2012; http://www.nber.org/papers/w18559.pdf?new window=1. 